\section{Comparison of Open-pollinated and Hybrid Onion Varieties for New Mexico}

\author{
Christopher S. Cramer ${ }^{1}$
}

ADDIfIONAL-AnDEX-WORds: Allium cepa, bolting, pink root, quality, yield

SUMMARY. Eighteen hybrid onion and 23 open-pollinated (OP) varieties were tested in southern New Mexico for plant characteristics, disease resistance, and bulb yield in order to determine if hybrid varieties outperformed OP varieties. Varieties were short- to intermediate-day in their bulbing response and were planted in the fall seasons of 1997 and 1998 and harvested the following May or June. Varieties were grouped based upon their relative maturity for fall-planted onions grown in southern New Mexico (early, intermediate, late). They were planted two (1998) or four (1997) rows per plot with plots being $8 \mathrm{ft}(2.5 \mathrm{~m})$ long and 22 inches $(56$ $\mathrm{cm})$ wide. Plant stand per plot, plant

\footnotetext{
This research was funded by the NMSU Agricultural Experiment Station and the New Mexico Dry Onion Commission. Thanks to Petoseed Co., Rio Colorado Seed Co., and Shamrock Seed Co. for the contribution of open-pollinated and hybrid onion varieties for this study. The author gratefully acknowledges technical assistance of Joe N. Corgan, and Jose Luis Mendoza. The cost of publishing this paper was defrayed in part by the payment of page charges. Under postal regulations, this paper therefore must be hereby marked advertisement solely to indicate this fact.

${ }^{1}$ Assistant professor of horticulture, Department of Agronomy and Horticulture, Box 30003, MSC 3Q New Mexico State University, Las Cruces, NM 88003 0003 .
}

height of seven plants, and leaf number of seven plants were measured $164 \mathrm{~d}$ after planting. Plots were harvested when $80 \%$ of the plant tops had fallen across all four replications of a single population. At harvest, number of seedstalks, number of bulbs, pink root incidence, and total bulb weight per plot were recorded. After removing culls, the percentage of marketable bulbs, marketable bulb yield, and average bulb size were determined. Hybrid varieties outperformed OP varieties for plant height, and leaf number but not for percentage of seedstalks, pink root incidence, percentage marketable yield, bulb size, and marketable bulb yield. In this study, most OP varieties perform as well or better than most of the hybrid varieties.

I n 1925, the discovery of cytoplasmic male sterility in the onion variety Italian Red by Jones and Emsweller (1936) led to the commercial production of hybrids (Havey, 1993). Before this time, all onion varieties were open-pollinated $(\mathrm{OP})$ varieties. OP varieties offered little genetic and marketing protection for seed companies since these varieties could be maintained by the grower or sold by another seed company under another name. The development of hybrid varieties offered protection to the seed company developing the hybrid, because the identity of the inbred lines used to develop the hybrid was protected. In addition, the hybrid could not be reproduced without the original inbred parents. Another benefit of hybrid varieties was the heterosis or hybrid vigor for many important horticultural traits when compared to the inbred lines used to develop the hybrid (Aghora and Pathak, 1991; Doruchowski, 1986; Dowker and Gordon, 1983; Hosfield et al., 1977; Hosfield et al., 1977; Jones and Davis, 1944; Joshi and Tandon, 1976). Onion suffers severe inbreeding depression with drastic decreases in growth, bulb size, and seed production after only two cycles of self-pollination (Jones and Davis, 1944). An additional benefit of hybrid varieties was their uniformity in plant and bulb characteristics between plants (Jones and Davis, 1944; Joshi and Tandon, 1976). If the parents used to develop the hybrid variety were uniform for plant and bulb characteristics, then each plant of the hybrid variety should be identi- cal genetically and the only variation observed would result from environmental effects. Therefore, onion hybrid varieties offered many benefits to seed companies and growers.

The development of hybrid varieties also presents disadvantages. The development of inbred parents used for hybrid production required more time than the development of OP varieties (Pike, 1986; van der Meer, 1994). In addition, hybrid seed is more expensive to produce than seed from OP varieties (van der Meer, 1994). As a result, the price of hybrid seed is two to three times higher than the price of $O P$ variety seed. Hybrid varieties were shown to exceed their inbred parents in terms of plant growth, bulb yield, and bulb quality (Jones and Davis, 1944; Joshi and Tandon, 1976). However, the plant and bulb characteristics of hybrid varieties did not exceed the same characteristics of OP varieties (Binkley and Jones, 1945; Sypien et al., 1978; Dowker and Fennell, 1981; Dowker and Gordon, 1983). As a result of these disadvantages, hybrid onion varieties have not been grown in many parts of the world because of their prohibitive cost to local growers, and lack of superior plant and bulb benefits as compared to OP varieties (Dowker and Gordon, 1983; van der Meer, 1994).

Each year, New Mexico grows 7,000 to 8,000 acres $(2,834$ to 3,239 ha) of onions with a total of 160,000 to 180,000 tons $(145,455$ to 163,636 t) produced and a value of $\$ 43$ to $\$ 53$ million (U.S. Dept. Agr., 2000). New Mexico has a long history of growing OP Grano onion varieties that were selected from 'New Mexico Early Grano' and 'New Mexico White Grano' (Corgan et al., 1997). Recently, hybrid varieties from commercial seed companies are being sold and grown in New Mexico for onion bulb production. OP and hybrid varieties have not been compared for their plant and bulb characteristics in this area. A multiyear, fall-planted study was conducted to compare the number of leaves per plant, average plant height, bolting percentage, pink root disease incidence (Phoma terrestris E.M. Hans.), percentage of marketable bulbs, bulb weight, and marketable yield of hybrid and OP onion varieties grown in southern New Mexico. The objective of the study was to determine if hybrid varieties outperform 
Table 1. Mean values for initial plant stand, plant height, leaf number, days to plant maturity, final plant stand, percentage of seedstalks, pink root rating, percentage marketable yield, marketable yield per acre, and bulb weight for openpollinated and hybrid varieties.

\begin{tabular}{|c|c|c|c|c|c|}
\hline Source & $\begin{array}{l}\text { Initial plant } \\
\text { stand }(\%)^{\mathrm{z}}\end{array}$ & $\begin{array}{c}\text { Plant } \\
\text { height (in) }\end{array}$ & $\begin{array}{c}\text { Leaf } \\
\text { number }\end{array}$ & $\begin{array}{c}\text { Maturity } \\
\text { (d) }\end{array}$ & $\begin{array}{l}\text { Final plant } \\
\text { stand }(\%)^{x}\end{array}$ \\
\hline Open-pollinated & 89.7 & 13.0 & 5.2 & 151 & 83.3 \\
\hline Hybrid & 88.7 & 14.8 & 5.5 & 144 & 84.6 \\
\hline F ratio & NS & $122.5^{* * *}$ & $38.9^{* \star \star}$ & $102^{* \star \star}$ & NS \\
\hline Source & $\begin{array}{c}\text { Seedstalks } \\
(\%)\end{array}$ & $\begin{array}{l}\text { Pink } \\
\text { root }\end{array}$ & $\begin{array}{c}\text { Marketable } \\
\text { yield (\%) }\end{array}$ & $\begin{array}{c}\text { Marketable } \\
\text { yield/acre } \\
\text { (no. 50-1b sacks) }^{\text {w }}\end{array}$ & $\begin{array}{c}\text { Bulb weight } \\
(\mathrm{oz})^{\mathrm{v}}\end{array}$ \\
\hline Open-pollinated & 9.8 & 3.1 & 87.6 & 1182 & 13.3 \\
\hline Hybrid & 38.5 & 3.1 & 79.9 & 837 & 14.1 \\
\hline F ratio & $198.0^{\star * *}$ & AS & $37.9^{\star \star *}$ & $68.6^{* \star *}$ & AS \\
\hline
\end{tabular}

${ }^{\mathrm{z}}$ Initial plant stand per plot at $164 \mathrm{~d}$ after planting.

${ }^{\mathrm{y}} 1.0 \mathrm{inch}=2.54 \mathrm{~cm}$.

${ }^{x}$ Final plant stand per plot at harvest.

${ }^{\mathrm{w}} 0.056$ (no. $50-\mathrm{lb}$ sacks $/$ acre $)=\mathrm{t} \cdot \mathrm{ha}^{-1}$.

${ }^{\mathrm{v}} 1.0 \mathrm{oz}=28.35 \mathrm{~g}$.

Nonsiginficant or significant at $P=0.001$, respectively.

OP varieties in terms of plant and bulb traits when grown in southern New Mexico.

\section{Materials and methods}

Forty-one onion open-pollinated (OP) (23) and hybrid (18) varieties (Table 1) were seeded on 16 Sept. 1997 and 15 Sept. 1998 at the Fabian Garcia Agricultural Science Center in Las Cruces, NM. Companies contributing varieties included New Mexico State University (NMSU), Petoseed Company (Peto) (Woodland, Calif.), Rio Colorado Seeds (RCS) (Bakersfield, Calif.), and Shamrock Seed Company (SSC) (Salinas, Calif.). The early planting date was chosen to evaluate entries for bolting resistance. Plots were $8 \mathrm{ft}(2.5 \mathrm{~m})$ long and 22 inches $(56$ $\mathrm{cm})$ wide with four (1997) or two (1998) rows equally spaced apart on a raised, shaped, standard vegetable bed. Plots were separated by $2 \mathrm{ft}(0.6 \mathrm{~m})$ alleys within the bed and $2 \mathrm{ft}$ furrows between beds. Seedlings within the plot were thinned on 25 Nov. 1997 and 18 Nov. 1998 to 4 inches $(10 \mathrm{~cm})$ between plants. Plants were grown using standard cultural practices for growing fall-planted onions in southern New Mexico (Corgan and Holland, 1990; Corgan et al., 2000; Cramer et al., 1998a, 2000). Plots were irrigated as needed using drip irrigation. They were fertilized with $30 \mathrm{ppm}\left(\mathrm{mg} \mathrm{kg}^{-1}\right)$ of URAN (urea and ammonium nitrate) 32 (32N-0P-0K) as needed. Before planting, diammonium phosphate (18N-20.1P$0 \mathrm{~K})$ was applied at a rate of $250 \mathrm{lb} /$ acre $\left(46 \mathrm{~kg} \cdot \mathrm{ha}^{-1}\right)$. Immediately after planting, DCPA was applied at a rate of $8 \mathrm{lb} /$ acre $\left(1.5 \mathrm{~kg} \cdot \mathrm{ha}^{-1}\right)$. During the growth of the crop, permethrin was applied at a rate (a.i.) of $0.7 \mathrm{oz} / \mathrm{acre}$ $\left(42.7 \mathrm{~mL} \cdot \mathrm{ha}^{-1}\right)$ to control onion thrips (Thripstabaci Lindeman) populations.

To facilitate harvest and to maintain plot to plot competition effects, varieties were grouped based on approximate bulb maturity for fallplanted onions grown in southern $\mathrm{New}$ Mexico (early, intermediate, late). Within each grouping, varieties were arranged in a randomized complete block design with four replications. Eleven OP and 14 hybrid varieties were included in the early-maturing group, while eight OP and three hybrid varieties were included in the intermediate-maturing group. One hybrid and four OP varieties were included in the late-maturing group.

On 28 Feb. 1998 and 26 Feb. 1999 (164 to $165 \mathrm{~d}$ after planting), the total number of plants was counted for each plot. In addition, five plants were randomly selected from each plot, and the number of leaves and plant height (from soil line to end of tallest leaf) were measured for each plant. The tallest and shortest plants in each plot were selected also, and the number of leaves and plant height were measured for those plants. An average plant height and number of leaves per plant was calculated for each plot.

Before harvest, the approximate date of maturity ( $80 \%$ of tops down) was calculated for each plot. All four replications of a particular variety were harvested when all of the plots exhibited $80 \%$ of the plants with their tops down. In addition to bulb maturity, the number of plants with flower scapes was counted. The percentage of flower scapes, a measure of bolting, was calculated by dividing the number of plants with scapes by the total number of plants per plot.

Varieties in the early-maturing group were harvested on 19 and 26 May 1998, and 14 and 25 May, and 3 June 1999, while varieties in the intermediate-maturing group were harvested on 27 May and 4 June 1998, and 25 May, 3, 8, and 15 June 1999. All varieties in the late-maturing group were harvested on 22 June 1998, and 22 and 25 June 1999. Before harvest, plots were undercut with a rod-weeder to disrupt the root system and facilitate harvesting. Once bulbs were removed from the ground, the total number was counted. Twenty-five randomly selected bulbs per plot were rated for pink root incidence using a subjective rating of 1 (no pink roots) to 9 (all roots infected). After the pink root reading, bulb tops and roots were clipped, and bulbs were placed in brown burlap sacks for field curing. Bulbs were cured at field conditions for $4 \mathrm{~d}$. After curing, the total bulb fresh weight was measured for each plot. Afterwards, bulbs were graded to remove culls (diseased bulbs, bulbs under 1 inch $(3.8 \mathrm{~cm})$ in diameter, split bulbs, double bulbs). The number of culls was subtracted from the total number of bulbs to yield the number of marketable bulbs per plot. The marketable bulbs per plot were weighed to measure the marketable fresh weight per plot. The percentage of marketable 
yield was calculated by dividing the marketable weight per plot by the total weight per plot. The average bulb weight was calculated by dividing total marketable bulb weight by total marketable bulb number per plot.

The means for each trait over four replications were calculated for each variety and for the sum of varieties within each variety type (OP or hybrid) using the Proc Means statement of the SAS statistical software (SAS Institute, Cary, N.C.). Within each variety type, differences between varieties were calculated for each trait using the Proc Anova statement of SAS.
In addition, a protected Fisher's least significant difference ( ration test was calculated at the $5 \%$ level for each trait using SAS.

\section{Results and discussion}

Hybrid varieties were taller [ 14.8 inches $(37.6 \mathrm{~cm})]$ and plants had more

Table 2. Source, maturity group, plant stand, plant height, leaf number, and maturity date for open-pollinated and hybrid onion varieties tested during 1998 and 1999.

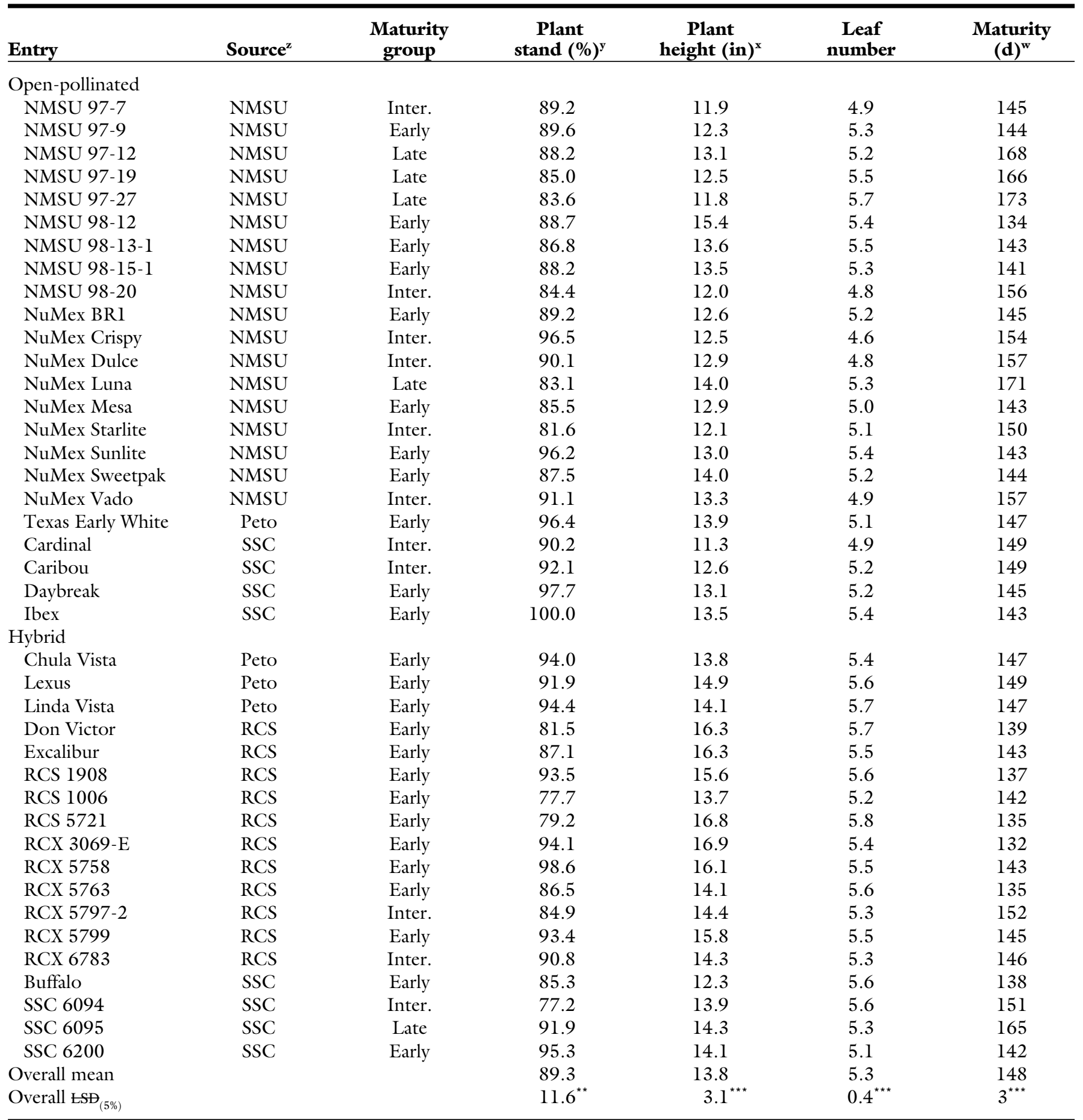

${ }^{\mathrm{z} N M S U}=$ New Mexico State University, Peto = Petoseed Company, RCS = Rio Colorado Seed Company, SSC = Shamrock Seed Company.

yInitial plant stand at $164 \mathrm{~d}$ after planting.

${ }^{x} 1.0$ inch $=2.54 \mathrm{~cm}$.

w Number of days from 1 Jan.

${ }^{\star *},{ }^{* * *}$ Significant at $P=0.01$ or 0.001 , respectively. 
leaves (5.5) than OP varieties [13.0 inches $(33.0 \mathrm{~cm})$ and 5.2 , respectively] 4 months before harvest (Table 1 ). However, this difference in height and leaf number did not correlate with a difference in marketable yield or bulb size (Table 1). OP varieties possessed a greater percent marketable yield $(87.6 \%)$ and total marketable yield [1182 50-lb sacks/acre $\left(66.2 \mathrm{t} \cdot \mathrm{ha}^{-1}\right)$ ] than hybrid varieties $[79.9 \%$ and 837 50-lb sacks/acre (46.9 t.ha-1), respectively] (Table 1). Hybrid varieties had taller plants and greater leaf numbers, but did not produce greater yields. The difference in marketable yield between the two groups was partially attributed to the difference in seedstalk production (Table 1 ). OP varieties used in this study were adapted to the growing conditions in southern New

Table 3. Plant stand, percentage of seedstalks, pink root rating, percentage marketable yield, marketable yield per acre, and bulb weight means for open-pollinated and hybrid onion varieties tested during 1998 and 1999.

\begin{tabular}{|c|c|c|c|c|c|c|}
\hline Entry & $\begin{array}{c}\text { Plant } \\
\text { stand }(\%)^{\mathrm{z}}\end{array}$ & $\begin{array}{c}\text { Seedstalks } \\
(\%)\end{array}$ & $\begin{array}{l}\text { Pink } \\
\text { root }\end{array}$ & $\begin{array}{c}\text { Marketable } \\
\text { yield (\%) }\end{array}$ & $\begin{array}{c}\text { Marketable } \\
\text { yield/acre } \\
\text { (no. 50-1b sacks) }^{\mathrm{y}}\end{array}$ & $\begin{array}{c}\text { Bulb wt w } \\
(\mathbf{o z})^{\mathbf{x}}\end{array}$ \\
\hline \multicolumn{7}{|l|}{ Open-pollinated } \\
\hline NMSU 97-7 & 94.0 & 1.1 & 4.3 & 88.5 & 1038 & 8.8 \\
\hline NMSU 97-9 & 83.5 & 1.6 & 2.7 & 82.9 & 1062 & 10.5 \\
\hline NMSU 97-12 & 65.0 & 10.7 & 3.1 & 89.3 & 940 & 12.1 \\
\hline NMSU 97-19 & 65.2 & 26.8 & 4.0 & 83.1 & 1079 & 17.9 \\
\hline NMSU 97-27 & 67.2 & 12.6 & 3.8 & 88.8 & 1285 & 17.3 \\
\hline NMSU 98-12 & 91.9 & 5.4 & 1.4 & 84.4 & 1017 & 9.6 \\
\hline NMSU 98-13-1 & 89.1 & 0.8 & 2.8 & 89.5 & 1498 & 13.4 \\
\hline NMSU 98-15-1 & 86.5 & 1.8 & 2.8 & 91.5 & 1485 & 14.0 \\
\hline NMSU 98-20 & 82.7 & 6.5 & 1.7 & 90.9 & 1581 & 15.8 \\
\hline NuMex BRl & 93.8 & 1.5 & 2.9 & 89.2 & 1468 & 12.4 \\
\hline NuMex Crispy & 90.1 & 13.2 & 1.9 & 85.8 & 1200 & 12.1 \\
\hline NuMex Dulce & 78.8 & 8.8 & 3.5 & 84.9 & 1379 & 15.5 \\
\hline NuMex Luna & 59.8 & 15.0 & 3.7 & 84.1 & 1028 & 16.6 \\
\hline NuMex Mesa & 84.1 & 1.9 & 2.5 & 88.3 & 1447 & 14.0 \\
\hline NuMex Starlite & 82.6 & 0.3 & 2.7 & 91.5 & 1659 & 15.8 \\
\hline NuMex Sunlite & 95.3 & 0.1 & 3.0 & 91.7 & 1742 & 14.2 \\
\hline NuMex Sweetpak & 80.9 & 23.9 & 2.9 & 78.8 & 951 & 13.1 \\
\hline NuMex Vado & 81.1 & 18.3 & 3.3 & 86.8 & 1157 & 13.9 \\
\hline Texas Early White & 89.2 & 43.9 & 2.4 & 85.5 & 753 & 11.9 \\
\hline Cardinal & 75.0 & 0.4 & 6.2 & 86.3 & 853 & 8.7 \\
\hline Caribou & 79.9 & 11.1 & 2.7 & 92.5 & 1187 & 13.1 \\
\hline Daybreak & 98.0 & 16.2 & 2.5 & 89.6 & 1344 & 12.8 \\
\hline Ibex & 100.0 & 3.1 & 3.6 & 89.9 & 1581 & 12.3 \\
\hline \multicolumn{7}{|l|}{ Hybrid } \\
\hline Chula Vista & 88.3 & 48.7 & 2.4 & 74.6 & 670 & 13.0 \\
\hline Lexus & 84.2 & 59.8 & 2.2 & 75.1 & 587 & 15.8 \\
\hline Linda Vista & 82.6 & 54.3 & 2.7 & 81.4 & 649 & 14.2 \\
\hline Don Victor & 81.4 & 52.7 & 2.8 & 84.7 & 944 & 16.7 \\
\hline Excalibur & 91.3 & 59.1 & 2.5 & 90.3 & 774 & 15.2 \\
\hline RCS 1006 & 89.2 & 40.0 & 2.7 & 56.7 & 430 & 9.3 \\
\hline RCS 1908 & 83.5 & 36.1 & 3.7 & 91.6 & 1123 & 15.0 \\
\hline RCS 5721 & 81.9 & 22.0 & 3.9 & 74.0 & 849 & 12.2 \\
\hline RCX 3069-E & 94.0 & 12.1 & 1.7 & 74.0 & 1168 & 12.5 \\
\hline RCX 5758 & 97.1 & 32.9 & 3.0 & 87.6 & 1328 & 16.0 \\
\hline RCX 5763 & 89.6 & 19.2 & 1.9 & 88.7 & 1110 & 11.9 \\
\hline RCX 5797-2 & 79.2 & 56.6 & 3.0 & 71.7 & 691 & 16.8 \\
\hline RCX 5799 & 93.0 & 21.3 & 2.3 & 82.9 & 1251 & 14.0 \\
\hline RCX 6783 & 92.4 & 32.5 & 1.9 & 88.4 & 1391 & 15.8 \\
\hline Buffalo & 71.2 & 1.0 & 7.3 & 87.2 & 849 & 10.4 \\
\hline SSC 6094 & 76.2 & 51.9 & 3.5 & 75.7 & 625 & 12.3 \\
\hline SSC 6095 & 55.7 & 65.9 & 3.8 & 69.0 & 366 & 19.5 \\
\hline SSC 6200 & 91.9 & 27.3 & 4.7 & 84.5 & 1087 & 12.9 \\
\hline Overall mean & 83.9 & 22.4 & 3.1 & 84.2 & 1031 & 13.6 \\
\hline Overall $\left\llcorner S \mathrm{~S}_{(5 \%)}\right.$ & $15.6^{* \star *}$ & $11.4^{* \star *}$ & $0.9^{* \star *}$ & $9.3^{* * *}$ & $262^{* * *}$ & $2.4^{* \star *}$ \\
\hline
\end{tabular}

${ }^{\mathrm{z}}$ Final plant stand per plot at harvest.

$\mathrm{y}_{0} 0.056$ (no. 50 -lb sacks $/$ acre $)=\mathrm{t} \cdot \mathrm{ha}^{-1}$.

${ }^{\mathrm{x}} 1.0 \mathrm{oz}=28.35 \mathrm{~g}$.

${ }^{* *}$ Significant at $P=0.001$. 
Mexico and as a result produced fewer seedstalks $(9.8 \%)$ than hybrid varieties $(38.5 \%)$ that were not adapted. The greater adaptation of the OP varieties may have also resulted in the greater percentage of marketable yield than the hybrid varieties. Hybrid varieties on average did produce larger bulbs than OP varieties (Table 1 ).

On average, hybrid varieties matured earlier (144 d) than OP varieties $(151 \mathrm{~d})$ (Table $\mathrm{l})$. This difference is partially due to the efforts of the NMSU onion breeding program to develop later-maturing varieties that are fall planted (Corgan et al., 1997; Cramer et al., 1998b). More of the later-maturing varieties were OP rather than hybrid varieties. Several of the hybrid varieties (e.g., 'Chula Vista', 'Lexus', 'Linda Vista') grown in this study were developed for areas that harvest before New Mexico.

The pink root ratings between the two groups were similar (Table 1 ). The rating for $\mathrm{OP}$ and hybrid varieties averaged 3.1 (Table 1). Most of the hybrid varieties possess good pink root resistance (Table 3), because other onion production areas besides New Mexico have pink root disease problems so commercial seed companies are developing varieties with high levels of pink root resistance. One of the breeding objectives of the NMSU onion breeding program has been to release $\mathrm{OP}$ varieties that possess good to excellent pink root resistance (Corgan et al., 1997; Cramer et al., 1998b).

Although trait differences existed between OP and hybrid varieties, trait means within each group varied considerably such that trait values overlapped between the two variety types. For example, plant height of the OP varieties ranged from 11.3 inches $(28.7$ $\mathrm{cm}$ ) ('Cardinal') to 15.4 inches (39.1 $\mathrm{cm}$ ) (NMSU 98-12) while the height range of the hybrid varieties was 12.3 inches $(31.2 \mathrm{~cm})$ ('Buffalo') to 16.9 inches $(42.9 \mathrm{~cm})(\mathrm{RCX} 3069-\mathrm{E})$ (Table $2)$. In addition, leaf number per plant of the OP varieties ranged from 4.6 ('NuMex Crispy') to 5.7 leaves (NMSU 97-19) while the leaf number of the hybrid varieties ranged from 5.1 (SSC 6200) to 5.8 leaves (RCS 5721) (Table 2).

Several OP and hybrid varieties performed well in this study and could be recommended for production in southern New Mexico. For the OP varieties, 'Ibex', NMSU 98-13-1, NMSU 98-15-1, NMSU 98-20, 'NuMex BRl', 'NuMex Dulce', 'NuMex Mesa', 'NuMex Starlite', and 'NuMex Sunlite' produced high yields of marketable bulbs, a high percentage of marketable bulbs, large bulb size, good bolting resistance, and a low incidence of pink root disease (Table $3)$. For the hybrid varieties, RCX 5758 , RCX 5799, and RCX 6783 produced high yields of marketable bulbs, large bulbs, and a low incidence of pink root disease (Table 3 ). The bulb yield per plot would have been greater if the percentage of seedstalks was lower. The percentage of seedstalks for the hybrid varieties might have been lower if the populations were planted later. However, a later planting may also result in decreased bulb size as compared to earlier plantings.

From previous studies, hybrid onion varieties have exhibited hybrid vigor and have outperformed inbred lines used in the hybrid development process (Jones and Davis, 1944; Joshi and Tandon, 1976; Hosfield et al., 1977; Dowker and Gordon, 1983; Doruchowski, 1986; Aghora and Pathak, 1991). However, hybrid varieties have not consistently outperformed locally adapted OP varieties (Binkley and Jones, 1945; Sypien et al., 1978; Dowker and Fennell, 1981; Dowker and Gordon, 1983). OP varieties, unlike inbred lines, do not suffer inbreeding depression for yield and vigor, because genetic variation is maintained through cross-pollination among individuals within the variety. However, OP varieties may lack the uniformity for maturity, pink root resistance, firmness, and bulb shape that hybrid varieties possess. In our study, hybrid varieties expressed vigor for plant characteristics and bulb size but did not outperform OP varieties for bolting resistance, pink root resistance, and bulb yield. Most of the OP varieties were developed in this area and are particularly well adapted to this area while the hybrid varieties were generally developed in other areas. For onion production in southern New Mexico, OP varieties generally performed as well as, if not better, than hybrid varieties.

\section{Literature cited}

Aghora, T. and C.S. Pathak. 1991. Heterosis and combining ability in a line $x$ tester cross of onions
(Allium cepa L.) Veg. Sci. (India) 18:53-58.

Binkley, A.M. and H.A. Jones. 1945. A comparison of sweet spanish hybrids with commercial sweet spanish onion strains. Proc. Amer. Soc. Hort. Sci. 45:485-487.

Corgan, J. and M. Holland. 1990. Onion cultivars and planting dates for southern New Mexico. N. Mex. Agr. Ext. Guide H-229.

Corgan, J.N., M.M. Wall, and C.S. Cramer. 1997. Onion genetic improvement at New Mexico State University. Allium Improvement Nwsl. 7:1-3.

Corgan, J.N., M.M. Wall, C.S. Cramer, T. Sammis, B Lewis, and J. Schroeder. 2000. Bulb onion culture and management. N.M. Coop. Ext. Serv. Circ. 563.

Cramer, C.S., J.L. Mendoza, and J.N. Corgan. 1998a. Fall-planted onion variety trials at New Mexico State University, p. 299-312. In: R.E. Voss (ed.). Proc. 1998 Natl. Onion (and other Allium) Res. Conf. Veg. Res. Info. Ctr., Univ. Calif., Davis, Calif.

Cramer, C.S., J.N. Corgan, J.L. Mendoza, and M.M. Wall. 2000. 1998-1999 Onion variety trials at New Mexico State University. N.M. Agr. Expt. Sta. Res. Rpt. 739.

Cramer, C.S., M.M. Wall, and J.N. Corgan. 1998b. Onion breeding research at New Mexico State University, p. 54-73. In: R.E. Voss (ed.). Proc. 1998 Natl. Onion (and Other Allium) Res. Conf. Veg. Res. Info. Ctr., Univ. Calif., Davis, Calif.

Doruchowski, R.W. 1986. Heterosis effect of some onion (Allium cepa L.) characteristics. Acta Agrobotanica 39:325-339.

Dowker, B.D. and J.F.M. Fennell. 1981. The relative performance of inbreds and open-pollinated populations of spring-sown onions. J. Agr. Sci. Cambridge 97:25-30.

Dowker, B.D. and G.H. Gordon. 1983. Heterosis and hybrid cultivars in onions, p. 220-233. In: R. Frankel (ed.) Monographs on theoretical and applied genetics, vol. 6. Heterosis. Springer-Verlag, Berlin.

Havey, M.J. 1993. Onion. Allium cepa L., p. 35-49. In: G. Kalloo and B.O. Bergh (eds.). Genetic improvement of vegetable crops. Pergamon Press, Inc., Terrytown, N.Y.

Hosfield, G.L., G. Vest, and C.E. Peterson. 1977. Heterosis and combining ability in a diallel cross of onions. J. Amer. Soc. Hort. Sci. 102:355-360.

Jones, H.A. and G.N. Davis. 1944. Inbreeding and heterosis and their relation to the development of new varieties of onions. USDA Tech. Bul. 874.

Jones, H.A. and S.L. Emsweller. 1936. A male-sterile onion. J. Amer. Soc. Hort. Sci. 34:582-585.

Joshi, H.C. and J.P. Tandon. 1976. Heterosis for yield and its genetic basis in onion. Indian J. Agr. Sci. 46:8892.

Pike, L.M. 1986. Onion breeding, p. 357-394. In: M. Bassett (ed.). Breeding vegetable crops. AVI Press, Westport, Conn.

Sypien, M., A. Kepka, and T. Kotlinska. 1978. Evaluation of Polish $\mathrm{F}_{1}$ hybrids of onions, as compared with standard cultivars of the wolska type. Biul. Warzywniczy 22:31-34

U.S. Department of Agriculture. 2000. Vegetables. 1999 Summary. Vg 1-2 (00). U.S. Govt. Printing Office, Wash., D.C.

van der Meer, Q.P. 1994. Onion hybrids: Evaluation, prospects, limitations, and methods, p. 243-247. Acta Hort. 358. Intl. Soc. Hort. Sci., The Hague, Belgium. 